Available online at GSC Online Press Directory

GSC Biological and Pharmaceutical Sciences

e-ISSN: 2581-3250, CODEN (USA): GBPSC2

Journal homepage: https://www.gsconlinepress.com/journals/gscbps

(RESEARCH ARTICLE)

\title{
Analysis of post-harvest treatment practices for kola (Cola nitida) using the HACCP system in three cities of Côte d'Ivoire
}

\author{
N’Guessan Jean-Marc 1, ${ }^{*}$, Nimaga Daouda ${ }^{2}$, Akpo Amenan Fanny ${ }^{1,3}$ and Amani N'Guessan Georges ${ }^{1}$ \\ ${ }^{1}$ Laboratory of Biochemistry and Technology of Tropical Products, UFR STA, Nangui Abrogoua University, 02 BP 801 \\ Abidjan 02, Côte d'Ivoire. \\ ${ }^{2}$ Department of Engineering Agronomy, Forest and Environment, University of Man, BP 20 Man Côte d'Ivoire. \\ ${ }^{3}$ Laboratory of Fruit and Vegetable Physiology, UMR Qualisud, University of Avignon, Jean Henri Fabre Campus, 301 \\ Baruch de Spinoza Street, BP21239 84916 Avignon cedex 9, France.
}

Publication history: Received on 19 June 2019; revised on 10 July 2019; accepted on 15 July 2019

Article DOI: https://doi.org/10.30574/gscbps.2019.8.1.0110

\begin{abstract}
The aim of this study is to propose a revised treatment scheme for fresh kola nuts (Cola nitida) using Hazard Analysis Critical Control Point (HACCP). Specifically, this will involve analysing the nut processing diagram used by the stakeholders, identifying critical points and proposing corrective measures for these critical points. A survey at kola producers and traders, coupled with an on-site diagnosis, was carried out in the cities of Anyama, Bouaké and Agboville. The verification of the preconditions was based on a checklist. In addition, the kola nut processing and storage system was evaluated according to the 12 steps of the HACCP system. The diagnosis of the sector revealed an informal organization and traditional practices. A revised diagram of the cola treatment process according to the HACCP system has been developed. This diagram includes three critical control points (CCPs) at the reception, sorting and biopesticide treatment level. A HACCP plan has been drafted to better monitor and control each critical point. The technical routes for processing cola do not guarantee good quality nuts. They do not comply with good hygiene practices (GHP) during the processing and storage process. The adoption and monitoring of the HACCP system would be beneficial for the kola industry.
\end{abstract}

Keywords: Cola nitida; Site diagnostics; Critical control points; HACCP system

\section{Introduction}

The kola tree Cola nitida (Wind) Schott and Endlicher, (family Sterculiaceae) is a plant found in Sub-Saharan Africa where it forms a vast natural stand in the forest area [1]. Côte d'Ivoire is the world's leading producer and exporter, with a production of 260,747 tonnes of fresh kola nuts in 2016 [2]. This production is mainly used for local consumption and export to neighbouring countries, particularly Nigeria, Mali, Niger, Senegal and Burkina Faso. However, in Côte d'Ivoire, the conditions under which kola nuts are packeging and stored cause enormous losses. Indeed, kola is attacked by weevils (Balanogastris kolae, Paremydica insperata), diptera (Pterandrus colae) and fungi (Fusarium sp., Penicillium sp., Aspergillus flavus, Alternaria sp., Aspergillus niger and Mucor spinosus) which can cause 30 to $70 \%$ loss during storage $[3,4]$. These insects and moulds are responsible for the deterioration of the market and sanitary qualities of the stored kola nuts. However, research on Ivorian kola is mostly focused on the agronomic aspect. Reducing production losses during handling and storage, including improving post-harvest processing systems, has been the subject of very few studies [5]. More effective control of food safety (including kola nuts) is essential to protect consumers from foodborne illness both nationally and internationally [6].

\footnotetext{
${ }^{*}$ Corresponding author

E-mail address: maguessan@gmail.com
} 
Many studies have shown the economic and social importance of kola nuts. Indeed, Ndemen [7] reports that in the far north of Cameroon, 89\% of wholesale traders involved in the marketing of kola derive most of their income from the sale of this product. However, its marketing is still essentially an informal activity, despite the fact that nuts are used in the brewing, food, pharmaceutical and dyeing industries [8, 9].

When the nuts are packaged, they are presented to the consumer with a precarious concern for hygiene, good presentation or adequate packaging. Thus, because of the difficulties in meeting the criteria of quality and the health requirements of developed countries related to food security, which is now a global concern (because of its importance for public health, but also because of its impact on international trade), effective food security systems must therefore manage and ensure the safety and security of food. It is in this sense that the deployment of a HACCP system fully plays this role.

The objective of this study is to propose a revised treatment scheme for fresh kola nuts (Cola nitida) using HACCP system. Specifically, this will involve analysing the nut processing diagram used by the stakeholders, identifying critical points and proposing corrective measures for these critical points.

\section{Material and methods}

\subsection{Study material}

The biological material consists of mature kola nuts of the species Cola nitida.

\subsection{Study sites}

The analysis of post-harvest kola treatment practices required surveys and field visits to three cities in Côte d'Ivoire. These are the cities of Anyama, Bouake and Agboville. A pilot store for the treatment and storage of kola nuts has been made available to us by the National Federation of Kola Professionals of Côte d'Ivoire (FENAPROCO-CI) for the implementation of the HACCP method.

\subsection{Methods}

\subsubsection{Prerequisite programs}

We have established an inventory of the kola nut processing and storage stores and their activities and we have assessed their situation before our intervention. To this end, we have inspected all the basic activities necessary to implement good hygiene and processing practices and HACCP. We have continued with the actual implementation of good hygiene and treatment practices that are not being applied or are being partially applied. Finally, we have implemented the HACCP method, which includes the analysis of hazards and critical points defined using a decision tree recommended by the Codex Alimentarius [10].

\subsubsection{Analysis by the HACCP system}

The impact of post-harvest processing practices on kola nut quality was assessed using the HACCP method as described by FAO [11].

\subsubsection{Building a multidisciplinary team}

The HACCP team was multidisciplinary and composed of 7 peoples led by a Coordinator (HACCP manager). It was made up of food technologists, toxicologists, quality experts and food microbiologists. The mission of this team was to evaluate processing practices from the receipt kola nuts with pulp to pre-sale storage. The identification of hazards associated with the processing, packaging and storage of cola nuts, as well as the assessment of their severity and frequency of occurrence, were carried out. Then the necessary means to control them and ensure their effectiveness were proposed and implemented. The analysis by the HACCP system was based on the product description until corrective action plans were established.

\subsubsection{Product description}

This description focused on information on the name, physico-chemical characteristics of kola, types of packaging, packaging and storage methods, target consumer population and expected use. 


\subsubsection{Construction and on-site verification of the kola nut processing diagram}

A detailed examination of the product flow and each step of the treatment and preservation process was carried out in order to establish a nut treatment diagram around which the HACCP analysis plan could be structured. The multidisciplinary team, after having constructed the manufacturing diagram and before starting operations, verified on site that the nut processing diagram and the plant plan corresponded to reality and that they allowed the hygienic operating conditions to be respected. All the new layouts of the treatment diagram were confronted with the traditional diagram.

\subsubsection{Hazard analysis}

The hazard listing consisted in identifying all biological, chemical and physical hazards that may occur during the unit operations of the kola treatment diagram. Therefore, preventive measures have been identified and proposed to prevent hazards from appearing or eliminating them to ensure the quality of the kola nut.

\subsubsection{Identification of critical points}

The identification of critical control points (CCPs) was based on the "decision tree" proposed by the Codex Alimentarius [12]. After analysing the hazards, identifying their levels of occurrence and causes, the HACCP team evaluated each step of the treatment diagram using the decision tree below (Figure 1) to identify the critical points.

\subsubsection{Establishment of critical limit}

The critical limits for each CCP identified, were established by a value; specified or inviolable maximum standard or condition that ensures that the CCP eliminates the identified hazard.

\subsubsection{Establishment of a monitoring and control system for each critical point}

For the various control parameters, a monitoring and control protocol allowing the respect of the critical limits or to take appropriate corrective measures has been defined.

\subsubsection{Establishment of a corrective action plan}

A monitoring system has been defined with measures to be observed at each critical point. This corrective action plan clearly indicates the persons responsible for the execution of the various corrective measures but also the actions to be taken regarding the products treated during the out-of-control periods. 


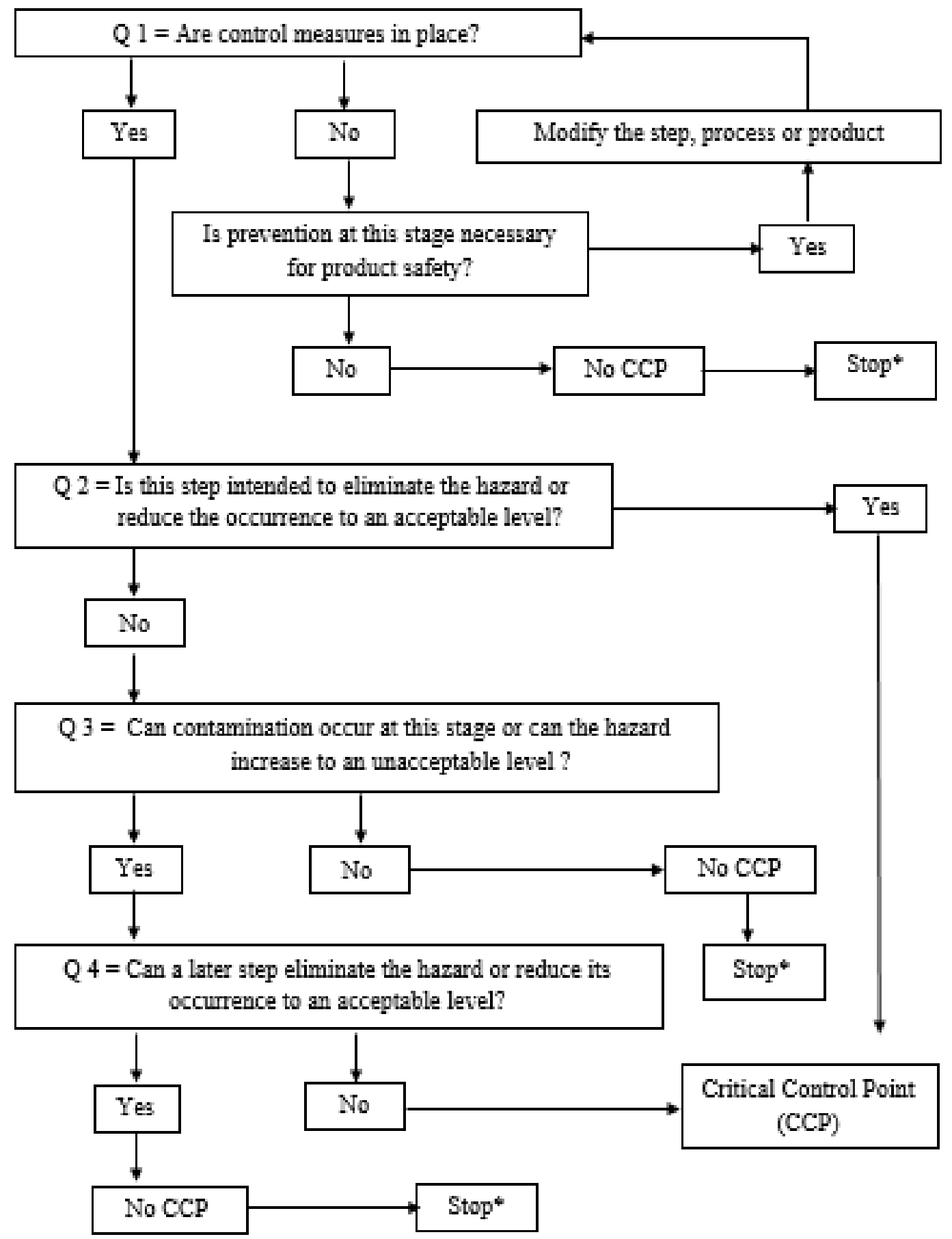

* The step is not a critical point. Proceed to the next step

Figure 1 Decision tree for the identification of critical control points (CCPs) 


\section{Results}

\subsection{Summary of the diagnosis of the cola sector}

Table 1 presents the assessment of the practices of treatments, storing kola nuts and the organization of the industry in the various cities surveyed according to the recommendations of the Prerequisite Program (PRP).

Table 1 Diagnosis of the sector according to the recommendations of the good hygiene practices (GHP)

\begin{tabular}{|c|c|c|c|c|}
\hline \multirow{2}{*}{$\begin{array}{l}\text { Sr. } \\
\text { No. }\end{array}$} & \multirow[t]{2}{*}{ Requirements } & \multicolumn{3}{|c|}{ Surveyed cities } \\
\hline & & Anyama & Agboville & Bouaké \\
\hline 1 & Premises & Not satisfying & Not satisfying & Not satisfying \\
\hline 2 & Facilities and workspace & Not satisfying & Not satisfying & Not satisfying \\
\hline 3 & Air, water and energy supply & Not satisfying & Not satisfying & Not satisfying \\
\hline 4 & Waste and wastewater disposal & Absent & Absent & Absent \\
\hline 5 & Appropriate equipment & Absent & Absent & Absent \\
\hline 6 & Management of purchased products & Absent & Absent & Absent \\
\hline 7 & $\begin{array}{l}\text { Measures to prevent cross- } \\
\text { contamination }\end{array}$ & Absent & Absent & Absent \\
\hline 8 & Cleaning and disinfection & Absent & Absent & Absent \\
\hline 9 & Pest control & Absent & Absent & Absent \\
\hline 10 & Hygiene of staff members & Not satisfying & Not satisfying & Not satisfying \\
\hline 11 & Staff training & Absent & Absent & Absent \\
\hline 12 & PRP Management & Absent & Absent & Absent \\
\hline 13 & Staff health policy & Absent & Absent & Absent \\
\hline 14 & $\begin{array}{l}\text { Contractual relationship with } \\
\text { suppliers and product management. }\end{array}$ & Not satisfying & Not satisfying & Not satisfying \\
\hline 15 & $\begin{array}{l}\text { Organization and commitment of the } \\
\text { Management }\end{array}$ & Not satisfying & Not satisfying & Not satisfying \\
\hline
\end{tabular}

\subsection{Drafting of the HACCP plan}

\subsubsection{Description of the product and its intended use}

Table 2 presents the description of the product and its intended use.

Table 2 Product description

\begin{tabular}{|c|c|}
\hline Parameters & Characteristic values \\
\hline Product name(s) & Kola \\
\hline & Bright colour (White, red and pink) \\
\hline Important product features & $\begin{array}{l}\text { Crunchy texture, Odourless, Bitter taste, weight }=18 \pm 4 \mathrm{~g} \text {, } \\
8.58 \% \text { protein, } 2.24 \% \text { fat, } 2.46 \% \text { fibre, } 2.8 \% \text { caffeine and } \\
0.05 \% \text { theobromine, } 0 \text { pathogens. }\end{array}$ \\
\hline Intended use of the product & $\begin{array}{l}\text { Direct consumption, production of energy drinks and } \\
\text { pharmaceutical drugs. }\end{array}$ \\
\hline Packaging & $\begin{array}{l}\text { Polyethylene bag, Rattan basket lined with } \\
\text { Thaumatococcus daniellii leaves, polvstyrene travs }\end{array}$ \\
\hline Duration of the conversation & 6 months at room temperature $\left(29 \pm 1^{\circ} \mathrm{C}\right)$ \\
\hline & Retail market in Côte d'Ivoire (neighbourhood), \\
\hline Place where the product is sold & $\begin{array}{l}\text { Wholesale market and to export to countries such as } \\
\text { Nigeria, Mali, Senegal and Burkina Faso }\end{array}$ \\
\hline Labelling instructions & $\begin{array}{l}\text { Origin of the kola (production area), type of nut (tamed } \\
\text { or wild plant), Name of buyer, Place of destination, Color } \\
\text { of nuts }\end{array}$ \\
\hline Special control devices during distribution & $\begin{array}{l}\text { Visual and manual verification of quality criteria, sorting, } \\
\text { washing and reconditioning }\end{array}$ \\
\hline
\end{tabular}




\subsubsection{Diagram of post-harvest treatment practices for kola nuts}

The diagram in Figure 2 shows the treatment of kola nuts from receipt of pulped nuts to storage. It includes improvements to the traditional diagram used by producers and traders. Indeed, new steps (soaking in the biopesticide ...) and a new input (polystyrene trays) have been added to the treatment diagram.

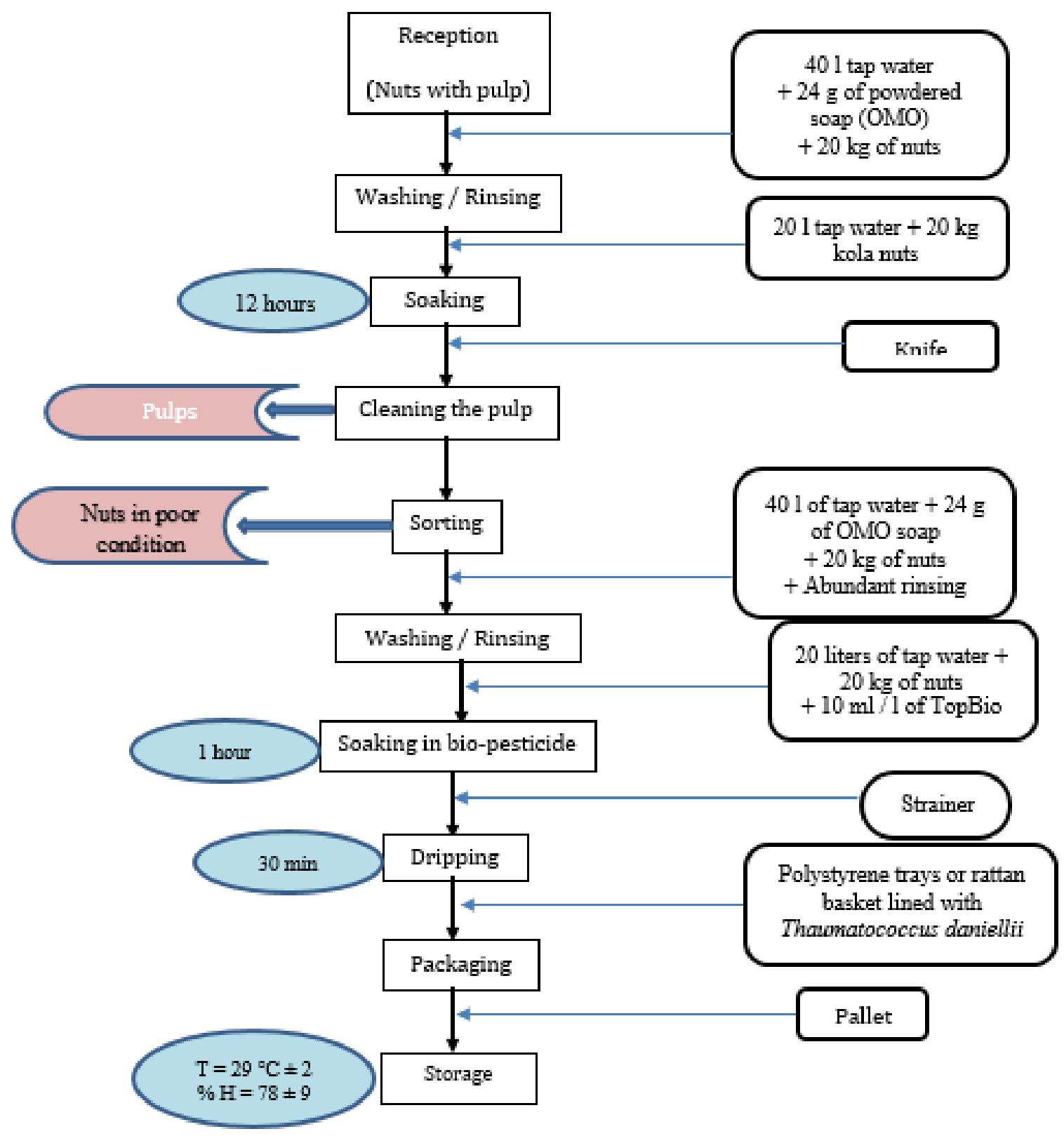

Figure 2 Diagram of post-harvest treatment of the kola nut ( $\mathrm{T}=$ Temperature, $\mathrm{H}=$ Relative humidity)

\subsubsection{Analysis of potential hazards}

Knowledge of the product and treatment processes made it possible to list potential hazards (physical, biological or chemical) and the conditions of their presence, severity, frequency and probability of manifestation at the different stages of kola nut processing (Table 3). Biological risks arise from openings in nut wounds, the nature and humidity of the supports or storage area and the poor quality of the water used. This would encourage the development of weevils, moulds and telluric bacteria at all stages of treatment. On the other hand, chemical risks are most often related to non-registration or non-compliance with the dosage of pesticides used. As for physical risks, they are related to foreign bodies, waste and the hygiene of the premises and staff. 
Table 3 Hazard analysis

\begin{tabular}{|c|c|c|c|}
\hline Steps & Hazard & Causes of the hazard & Control measure \\
\hline \multirow[t]{4}{*}{ Reception } & $\begin{array}{l}\text { B1. Risks related to pests and } \\
\text { microorganisms }\end{array}$ & $\begin{array}{l}\text { B1. Opening of kola nuts during } \\
\text { dehulling }\end{array}$ & $\begin{array}{l}\text { B1. - Visual inspection, Use of } \\
\text { disinfectant when washing or } \\
\text { soaking in biopesticide could } \\
\text { eliminate this risk }\end{array}$ \\
\hline & $\begin{array}{l}\text { C1. Risks related to pesticide } \\
\text { residues }\end{array}$ & C1. Spraying of pods & $\begin{array}{l}\text { C1. Use of registered pesticides } \\
\text { and compliance with prescribed } \\
\text { rates }\end{array}$ \\
\hline & $\begin{array}{l}\text { P1. Risks related to foreign } \\
\text { bodies }\end{array}$ & $\begin{array}{l}\text { P1. Unsorted nuts before } \\
\text { packaging for transport }\end{array}$ & P1. Visual inspection on receipt \\
\hline & $\begin{array}{l}\text { P2. Risks related to shocks } \\
\text { during transport }\end{array}$ & $\begin{array}{l}\text { P2. Incorrect handling during } \\
\text { loading and unloading of nut } \\
\text { transport trucks }\end{array}$ & $\begin{array}{l}\text { P } 2 \text { Control during loading and } \\
\text { unloading }\end{array}$ \\
\hline \multirow[t]{2}{*}{$\begin{array}{l}\text { Washing \& } \\
\text { Rinsing }\end{array}$} & $\begin{array}{l}\text { B2. Biological risk related to } \\
\text { water quality }\end{array}$ & $\begin{array}{l}\text { B2. Use of poor quality water } \\
\text { Soaking, Human Handling and } \\
\text { Cross-contamination }\end{array}$ & $\begin{array}{l}\text { B2. Use good quality water and } \\
\text { comply with GHPs }\end{array}$ \\
\hline & $\begin{array}{l}\text { C2. Chemical risk related to } \\
\text { detergent }\end{array}$ & $\begin{array}{l}\text { C2. Failure to comply with the } \\
\text { prescribed dosage and } \\
\text { insufficient rinsing }\end{array}$ & $\begin{array}{l}\text { C2. -Comply with the } \\
\text { requirements indicated on the } \\
\text { labelling of detergents, -Efficient } \\
\text { rinsing }\end{array}$ \\
\hline Soaking & $\begin{array}{l}\text { B3. Biological risk related to } \\
\text { water quality }\end{array}$ & $\begin{array}{l}\text { B3. Use of poor quality water } \\
\text { Soaking, Human Handling and } \\
\text { Cross-contamination }\end{array}$ & B3. Use good quality water \\
\hline \multirow[t]{2}{*}{$\begin{array}{l}\text { Cleaning the } \\
\text { pulp }\end{array}$} & $\begin{array}{l}\text { B4. Biological risk related to } \\
\text { microorganisms }\end{array}$ & $\begin{array}{l}\text { B4. Nut injuries and human } \\
\text { handling }\end{array}$ & $\begin{array}{l}\text { B4. The use of disinfectant } \\
\text { during washing could eliminate } \\
\text { this risk }\end{array}$ \\
\hline & $\begin{array}{l}\text { P3. Physical risks related to } \\
\text { objects used for pulping }\end{array}$ & $\begin{array}{l}\text { P3. Use of sharp objects (knife) } \\
\text { and/or piece of wood for } \\
\text { pulping }\end{array}$ & $\begin{array}{l}\text { P3. Compliance with GHPs / } \\
\text { Training }\end{array}$ \\
\hline Sorting & $\begin{array}{l}\text { P4. Physical risks related to } \\
\text { foreign bodies and nuts in poor } \\
\text { condition }\end{array}$ & P4. Non-compliance with GHPs & $\begin{array}{l}\text { P4. Compliance with } \mathrm{BPH} \text {, } \\
\text { Training }\end{array}$ \\
\hline \multirow[t]{2}{*}{$\begin{array}{l}\text { Washing \& } \\
\text { Rinsing }\end{array}$} & $\begin{array}{l}\text { B5. Biological risks related to } \\
\text { cross-contamination } \\
\text { (microorganisms) and water } \\
\text { quality }\end{array}$ & $\begin{array}{l}\text { B5. Human handling and cross- } \\
\text { contamination }\end{array}$ & $\begin{array}{l}\text { B5. Compliance with } \mathrm{BPH} \text {, } \\
\text { Training }\end{array}$ \\
\hline & $\begin{array}{l}\text { C3. Chemical risk related to } \\
\text { detergent }\end{array}$ & $\begin{array}{l}\text { C3. Failure to comply with the } \\
\text { prescribed dosage and } \\
\text { insufficient rinsing }\end{array}$ & $\begin{array}{l}\text { C3. Respect the prescribed } \\
\text { doses of detergent and rinse } \\
\text { well }\end{array}$ \\
\hline \multirow[t]{3}{*}{$\begin{array}{l}\text { Soaking in } \\
\text { biopesticide }\end{array}$} & $\begin{array}{l}\text { B6. Biological risk from water } \\
\text { quality }\end{array}$ & $\begin{array}{l}\text { B6. Contact of poor quality } \\
\text { water with nuts }\end{array}$ & $\begin{array}{l}\text { B6. Use good quality water, } \\
\text { Respect of GHPs, Training }\end{array}$ \\
\hline & $\begin{array}{l}\text { C4. Chemical risk related to } \\
\text { biopesticides }\end{array}$ & $\begin{array}{l}\text { C4. Failure to comply with the } \\
\text { prescribed dosage and } \\
\text { insufficient dripping }\end{array}$ & $\begin{array}{l}\text { C4. Use the approved } \\
\text { biopesticides and follow the } \\
\text { prescribed doses }\end{array}$ \\
\hline & $\begin{array}{l}\text { P5. Physical risk related to } \\
\text { personal belongings }\end{array}$ & P5. Non-compliance with GHPs & P5. Respect for GHPs, Training \\
\hline \multirow[t]{2}{*}{ Dripping } & $\begin{array}{l}\text { B7. Biological risks related to } \\
\text { cross-contamination }\end{array}$ & $\begin{array}{l}\text { B7. Human handling and cross- } \\
\text { contamination }\end{array}$ & B7. Respect for GHPs, Training \\
\hline & $\begin{array}{l}\text { P6. Physical risk related to } \\
\text { personal belongings }\end{array}$ & P6. Non-compliance with GHPs & P6. Respect for GHPs, Training \\
\hline \multirow[t]{2}{*}{ Packaging } & $\begin{array}{l}\text { B8. Biological risk related to } \\
\text { pests and microorganisms }\end{array}$ & $\begin{array}{l}\text { B8. Human handling and cross- } \\
\text { contamination }\end{array}$ & B8. Respect for GHPs, Training \\
\hline & $\begin{array}{l}\text { P7. Physical risk related to } \\
\text { personal belongings }\end{array}$ & P7. Non-compliance with GHPs & P7. Respect for GHPs, Training \\
\hline
\end{tabular}




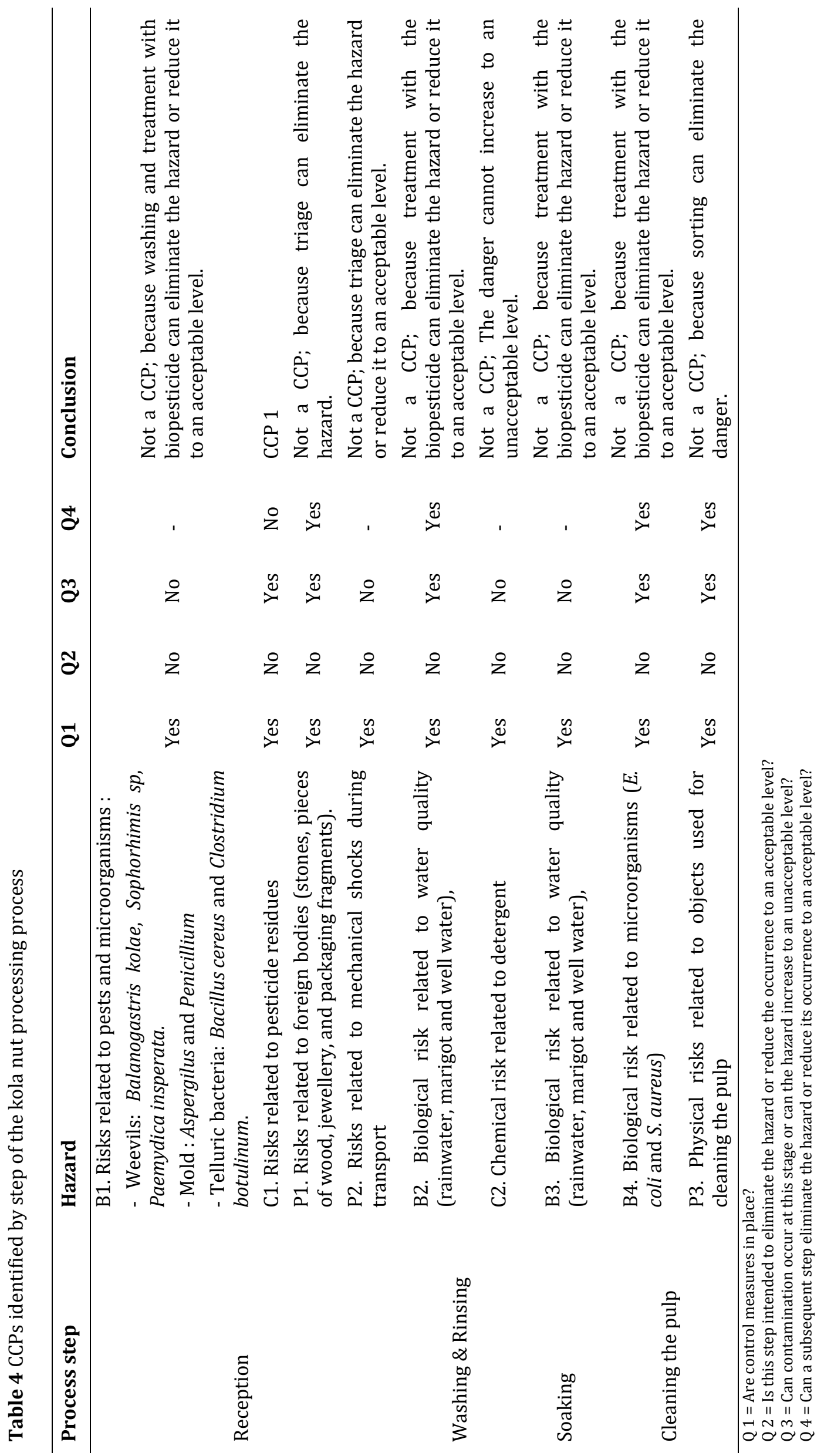




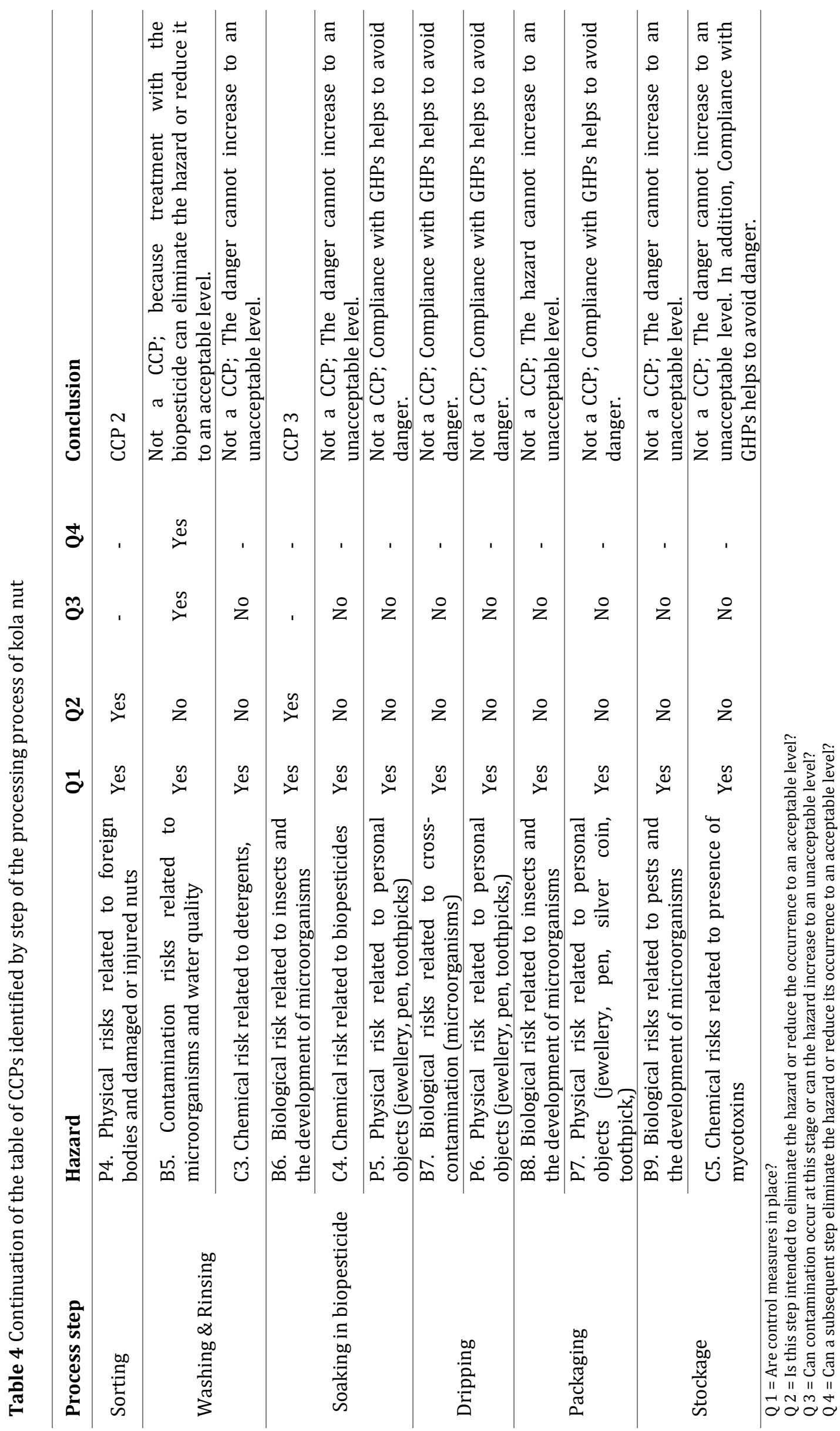




\subsubsection{CCPs identified}

The kola nut processing diagram (Figure 2) includes three Critical Control Points (CCPs). These CCPs concern the reception of the product, sorting and soaking in the biopesticide. Indeed, at the reception there is a chemical CCP related to the potential risks of pesticide residues in kola nuts. Then, a physical CCP at the sorting stage, because this stage is specifically designed to eliminate all waste, foreign bodies and mitted nuts during the treatment process. Finally, a biological CCP at the soaking stage in the biopesticide. Because this very essential step in the kola treatment process has been designed to control the possible proliferation of fungi and weevils. The other risks listed are not CCPs because they can be eliminated or reduced to an acceptable level by steps downstream of the diagram or controlled by the application of GHP (Table 4).

\subsubsection{Establishment of critical limits for each CCP}

The critical limits of the CCPs identified are presented in Table 5. To minimize the chemical risk related to pesticide residues upon receipt, all the chemicals used must be approved, but also the strict adherence to the dosages given by the manufacturers. If necessary, whatever the risk, adjust or stop the washing and remove the affected lot of kola nuts. The physical danger during sorting is due to the presence of foreign bodies, kola nuts stung by insects and injured nuts. Zero tolerance must be applied because of the risk of pest proliferation and rotting of nuts. As for the biological hazard related to weevils, microorganisms and the source of the water (quality), at the soaking step in the biopesticide, it is necessary to apply the limits for each microorganism but especially to be very rigorous for molds because of the danger posed by the toxins produced on health. Care must be taken to apply good hygiene practices for the bags and the storage site and to carry out frequent analyzes of the mold load (Penicillium and Aspergillus).

Table 5 Critical limits established for each CCP

\begin{tabular}{lll}
\hline Steps & Hazards & Critical limits \\
\hline Reception & $\begin{array}{l}\text { C1. Chemical related to } \\
\text { pesticide residues }\end{array}$ & $\begin{array}{l}\text { Regulation (EC) No 396/2005 of the European } \\
\text { Parliament and of the Council of 23 February } \\
\text { 2005 on maximum residue levels of pesticides in } \\
\text { or on food and feed of plant and animal origin } \\
\text { and amending Council Directive 91/414/EEC }\end{array}$ \\
& & $\begin{array}{l}\text { Zero tolerance (Absence) } \\
\text { Sorting }\end{array}$ \\
$\begin{array}{l}\text { P4. Physics related to foreign } \\
\text { bodies and nuts mitted or in } \\
\text { bad condition }\end{array}$ & \\
$\begin{array}{l}\text { Soaking in } \\
\text { the } \\
\text { biopesticide }\end{array}$ & $\begin{array}{l}\text { B6. Biological related to } \\
\text { weevils, microorganisms and } \\
\text { water source (quality) }\end{array}$ & $\begin{array}{l}\text {-Application of the limit for each microorganism } \\
\text { in accordance with the regulations } \\
\end{array}$ \\
\hline
\end{tabular}

\subsubsection{Establishment of surveillance measures and corrective measures}

The monitoring measures and corrective actions of the identified CCPs will be regularly evaluated by the person responsible for their control procedures who will ensure that a record of the reports is maintained (Table 6). 


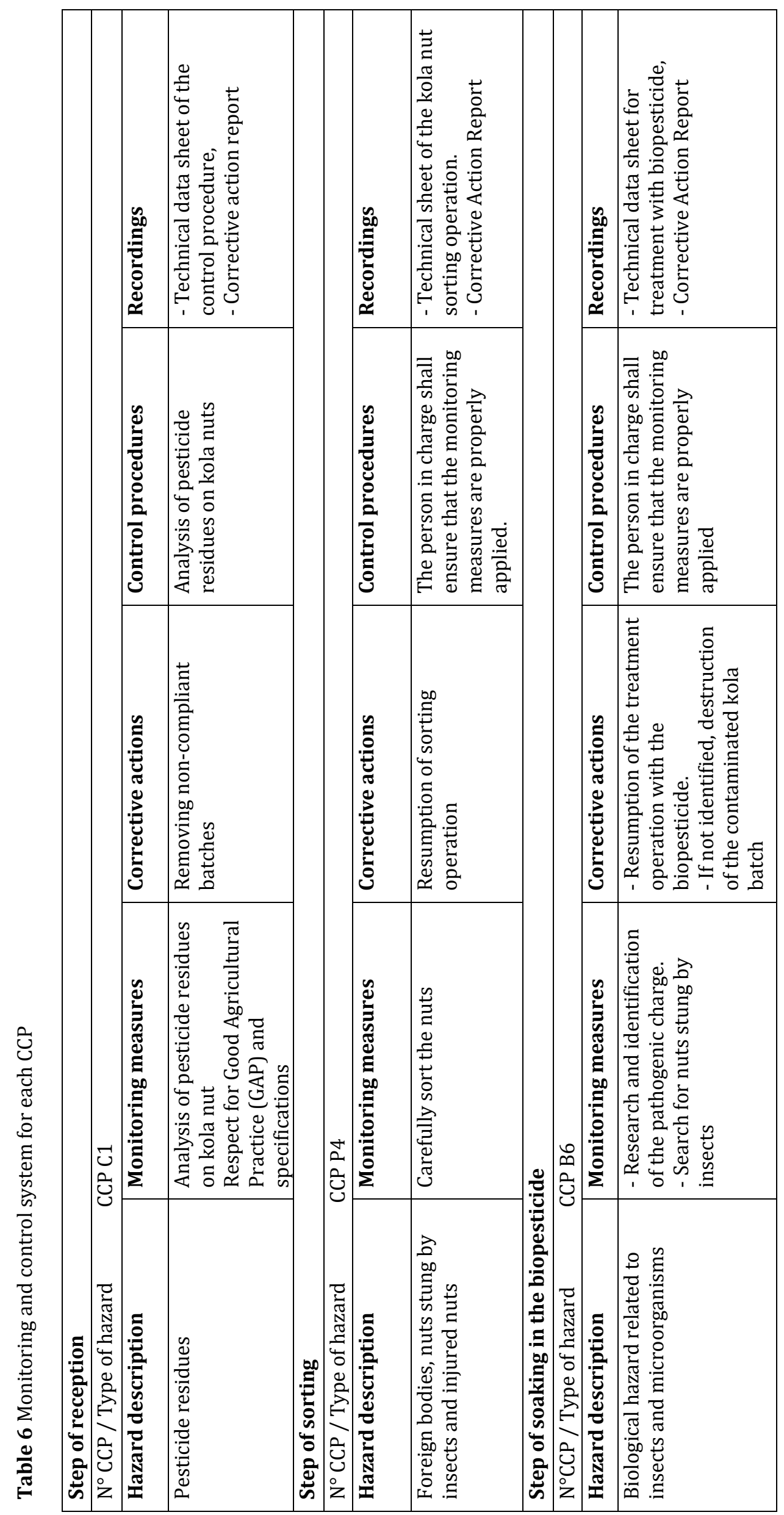




\section{Discussion}

During this study, it was observed that the activity of production and processing of kola being in the informal, the whole of the practices of treatment of the nuts applied, to the store of storage is source of enormous losses. In addition, no kola nut processing and storage center, surveyed cities (Anyama, Bouaké and Agboville) comply with the recommendations of the Prerequisite Program (PRP). Merchants do not have a developed pest plan. During the treatment of nuts, some actors use soap powder for washing and disinfecting nuts.

The risk analysis revealed several potentials for contamination in the walnut processing process. Indeed, all the data collected shows that the treatment as applied is generally done under unhygienic conditions and often with dangerous behaviors and habits. This favors a microbial proliferation presenting a major risk due to a lack of a training program in Good Hygiene Practices for the benefit of the staff of the kola industry. Several studies have shown that employees are the source of food contamination. In fact, the hygiene of the staff is an essential point to avoid cross contamination during the process of treating nuts. Also, the hands that are most often in direct contact with foodstuffs, should be considered in this sector of activity, as the first tool. In this respect, particular attention must be paid to their cleanliness as well as to the equipment made available to the operators for washing them. According to Bonne and al. [13], if the hands are not subjected to strict hygiene rules, constitute the first vector between the germs (possibly pathogenic) carried by the organism of the operators and the food. This comes down to the application of Good Hygiene Practices (GHP) and Good Manufacturing Practices (GMP) at the production sites that are essential to guarantee the quality and safety of a food. The treatment of kola nuts should begin with a first wash of the nuts with the pulp to remove the soil, followed by another wash after pulping and finally soaking in a biopesticide treatment solution. Sorting (removal of infested nuts, waste and foreign matter), washing and biopesticide treatment are essential steps, because if pathogens are not eliminated, neutralized or controlled, they can spread and contaminate the entire stock of kola.

\section{Conclusion}

This study made it possible to better understand and evaluate the different practices of post-harvest processing of kola nuts. The triage stage is a particular CCP to be mastered to avoid physical hazards (foreign bodies, mothed nuts and injured nuts), but also an essential control point to prevent the development of weevils. Indeed, any lot of nuts containing larvae of weevils or weevils will be destroyed under the activity of this insect during its development.

Despite the willingness of actors to have organizational sanitation at the level of the sector, they are still going through difficult times. The sector therefore remains poorly organized and informal. However, the organizational sanitation of the sector is a prerequisite for obtaining training in good practices for treating nuts, as well as obtaining financing and international markets. Thus, in the light of all these findings, a policy can be put in place to comply with the basic recommendations of the Good Hygiene Practices (GHP) before a concrete implementation of the HACCP system at the level of all producers and traders of the kola in Côte d'Ivoire.

\section{Compliance with ethical standards}

\section{Acknowledgments}

The authors would like to thank the Interprofessional Fund for Agricultural Research and Council (FIRCA), in Côte d'Ivoire, which financed this study: (Projet $N^{\circ}$ 063/FIRCA/LBATPT/FILIERE COLA/2016). They would also like to thank Professor KOUADIO James Halbin, Professor DIAKITE Aïssata, Dr. ADOU Marc and Dr AKELY Pierre Martial Thierry for their technical support. They also thank Mr. DIARRASSOUBA Aboudramane, President of FENAPROCO-CI (National Federation of Cola Professionals in Côte d'Ivoire) for allowing to conduct this study in these premises.

\section{Disclosure of conflict of interest}

The authors declare that there is no conflict of interest in the publication of this manuscript. 


\section{References}

[1] Bonsson B. (1983). Improvement of kola nut production in Côte d'Ivoire: selection principles. Coffee Cocoa Tea, 27 (4), 283-297.

[2] SARA. (2017). International Fair of Agriculture and Animal Resources. Structural transformation of the agricultural economy in the face of climate change. SARA Catalogue 2017. 86.

[3] Dembele A, Traore SK, Kone M, Konate D and Toure AA. (2008). Chemical control of kola nut preservation: quality management and compliance with phytosanitary regulations. European Journal of Scientific Research, 19 (3), 568-575.

[4] Nimaga D. (2015). Influence of post-harvest treatments on biochemical and organoleptic quality of kola nuts (Cola nitida) during storage. Phd, Nangui Abrogoua University, Abidjan, Côte d'Ivoire, 162.

[5] CNRA (2017). Inventory of research on the kola tree. Literature review. 18.

[6] FAO/WHO. (1997). "Risk management and food safety". Report of a joint FAO/WHO consultation, Rome. 35.

[7] Ndemen JB. (2009). Kola: Commercial transactions: Overview of the kola market in Cameroun, « La voix du Paysan » - Monthly magazine for rural entrepreneurs.

[8] Irvine FR. (1956). Plants of the Gold Coast. Oxford University Press. H. Milford, Londres, 327.

[9] Opeke LK. (1992). Tropical tree crops. Spectrum Books Ltd. Ibadan. 608.

[10] Codex Alimentarius (2003). Appendix Hazard Analysis and Critical Control Point (HACCP) Risk Analysis System and Guidelines for its Application. In: Codex Alimentarius. General principles of food safety. FAO and WHO, Geneva, Switzerland. 31-47.

[11] FAO (1996). Application of principles of the Hazard Analysis and Critical Control Point (HACCP) system in the control of food products. Rome, Italy, 42.

[12] Codex Alimentarius (2005). Residues in food. Joint FAO/WHO Food standard program. Rome, 61-81.

[13] Bonne R, Wright N, Camberou L and Boccas F. (2005). Guidelines on HACCP, Good Manufacturing Practices and Good Safety Practices for SMEs. 105.

\section{How to cite this article}

N'Guessan JM, Nimaga D, Akpo AF and Amani NG. (2019). Analysis of post-harvest treatment practices for kola (Cola nitida) using the haccp system in three cities of Côte d'Ivoire. GSC Biological and Pharmaceutical Sciences, 8(1), 51-63. 